\title{
HAZARD ANALYSIS CRITICAL CONTROL POINT (HACCP) SEBAGAI MODEL KENDALI DAN PENJAMINAN MUTU PRODUKSI PANGAN
}

\author{
(Studi Pada Perkuliahan Pastry di Sekolah Tinggi Pariwisata Bandung)
}

\author{
Lien Maulina Cartwright ${ }^{1} \quad$ Diah Latifah ${ }^{2}$
}

\begin{abstract}
Abstrak : Penelitian ini pada dasarnya dilandasi oleh pemikiran bahwa keamanan pangan khususnya dalam bidang pembuatan pastry menjadi sesuatu yang sangat penting. Tujuan dari penelitian ini adalah: 1) Menganalisis tahapan-tahapan penting dalam pengolahan pastry untuk menjamin mutu pastry; 2) Mengevaluasi cara pengawasan dan pengendalian mutu pada pengolahan pastry; dan 3) mengevaluasi kelayakan dasar dan tingkatan penerapan HACCP dari Unit Pengolahan pastry . Penelitian ini menggunakan metode deskriptif. Teknik pengumpulan data berupa observasi dan wawancara. Hasil penelitian memberikan gambaran sebagai berikut : 1) Tahapan-tahapan pada pengolahan Pastry telah menerapkan 7 prinsip HACCP; 2) Pengawasan dan pengendalian mutu pada pengolahan pastry sudah sesuai dengan konsep HACCP; 3) Kelayakan dasar dan tingkatan penerapan HACCP pada pengolahan Pastry berturut-turut sebagai berikut : baik, baik, dan baik sekali.
\end{abstract}

\begin{abstract}
This research is basically based on the premise that food security especially in the field of pastry making into something very important. The purpose of this study are: 1) to analyze important stages in the processing of pastry to ensure the quality of pastry; 2) Evaluate how the supervision and quality control in the processing of pastry, and 3) evaluate the basic feasibility and level of implementation of HACCP Processing Unit pastry. This research use descriptive method. In collecting observations and interviews. The results give an idea as follows: 1) The stages in the processing Pastry has adopted 7 principles of HACCP; 2) Supervision and quality control in the manufacture of pastry is in compliance with the HACCP concept, 3) the basic feasibility and level of implementation of HACCP in the processing of consecutive Pastry as follows: good, good and excellent.
\end{abstract}

Kata kunci : HACCP, Kendali dan Penjaminan Mutu, Perkuliahan Pastry

\section{PENDAHULUAN}

Perkembangan industry Pastry pada saat ini sangat berkembang.Berbagai produk Pastry telah menjadi primadona tersendiri dalam industri makanan di Indonesia. Berbagai industri makanan yang ada saat ini pada dasarnya perlu memperhatikan jaminan keamanan pangan. Hal ini didorong oleh semakin tingginya tuntutan masyarakat terhadap kualitas produk-produk pangan yang dikonsumsi. Penyebaran informasi yang sangat cepat melalui media massa mengenai kasus-kasus keracunan pangan dan bahayabahaya yang dikandung dalam bahan pangan menyebabkan masyarakat semakin teredukasi dan selektif dalam memilih produk-produk pangan yang beredar di pasaran. Maskur (2007) menyebutkan bahwa sepanjang empat tahun terakhir, industri jasa boga (katering) dan produk makanan rumah tangga menjadi penyebab terbesar keracunan pangan yaitu $31 \%$, diikuti oleh pangan olahan sebesar $20 \%$, jajanan 13\%, dan lain-lain 5\%. Akan tetapi jumlah kasus keracunan makanan yang diberitakan di media massa tidak sebanyak laporan yang diterima oleh Badan Pengawasan Obat dan Makanan (BPOM), yang disebabkan terbatasnya jumlah media massa yang tersedia dalam bentuk online dan tidak semua lokasi di Indonesia dapat terjangkau oleh pemberitaan media massa (Siswono, 2006). WHO (1998) di dalam 
Cahyono (2007) menyebutkan bahwa perbandingan antara kasus keracunan pangan yang dilaporkan dan yang sebenarnya terjadi adalah $1: 10$ untuk negara maju dan $1: 25$ untuk negara berkembang. Setiap negara mempunyai kewenangan untuk memberikan perlindungan terhadap masyarakatnya.

Di Indonesia, salah satu upaya pemerintah untuk melindungi konsumen dan produsen akan pangan yang sehat dan aman adalah dengan memberlakukan UndangUndang RI No. 23 Tahun 1992 tentang Kesehatan (Bagian Keempat: Pengamanan Makanan dan Minuman), Undang- Undang RI No. 7 Tahun 1996 tentang Pangan, Peraturan Pemerintah No. 69 Tahun 1999 tentang Label dan Iklan Pangan, Peraturan Pemerintah No. 28 Tahun 2004 tentang Keamanan, Mutu dan Gizi Pangan. Pemerintah Indonesia juga telah memiliki Undang-Undang No. 8 Tahun 1999 tentang Perlindungan Konsumen. Namun Cahyono (2007) menyebutkan gambaran keamanan pangan saat ini di Indonesia adalah masih ditemukan beredarnya produk pangan yang tidak memenuhi persyaratan, masih banyak dijumpai kasus keracunan makanan, masih rendahnya tanggung jawab dan kesadaran produsen serta distributor tentang keamanan pangan yang diproduksi, dan masih kurangnya kepedulian dan pengetahuan konsumen terhadap keamanan pangan. Dampak buruk keracunan pangan bagi masyarakat adalah kerugian ekonomis, sakit atau meninggal pada korban keracunan, berkurangnya produktivitas kerja maupun terancamnya status kesehatan masyarakat dalam jangka panjang (Siswono, 2006). Adanya kasus-kasus mengenai keracunan pangan di seluruh dunia menyebabkan berbagai negara telah mengangkat isu keamanan pangan ke dalam dunia perdagangan. Beberapa negara menjadikan masalah keamanan pangan sebagai isu yang perlu diatur secara wajib (mandatory) dan negara lain ada yang mengaturnya secara sukarela (voluntary). Di Indonesia sendiri, Badan Standarisasi Nasional (BSN) masih mengatur masalah keamanan pangan secara sukarela, dan BPOM baru mewajibkan prerequisite system keamanan pangan melalui sertifikasi Cara Produksi Pangan yang Baik (Thaheer, 2005). Oleh karena keamanan pangan menjadi sangat penting di dunia perdagangan, industri pangan harus dapat menjamin produk-produknya aman untuk dikonsumsi, sehingga mampu bersaing dengan industri sejenisnya dan bahkan mampu mengekspor produknya. Produk yang aman merupakan persyaratan yang dituntut konsumen di samping penampilan, cita rasa, dan harga. Produsen memiliki tanggung jawab untuk memenuhi harapan konsumen tersebut (Mortimore dan Wallace, 1995).

Untuk itulah sistem Hazard Analysis Critical Control Points (HACCP) mulai diterapkan di banyak negara di dunia. HACCP adalah suatu sstem jaminan mutu yang mendasarkan pada kesadaran atau perhatian bahwa bahaya (hazard) akan timbul pada berbagai titik atau tahap produksi, tetapi dapat dilakukan tindakan pengendalian untuk mengontrol bahaya. HACCP merupakan salah satu bentuk manajemen risiko yang dikembangkan untuk menjamin keamanan pangan dengan pendekatan pencegahan (preventive) yang dianggap dapat memberikan jaminan yang dianggap dapat memberikan jaminan dalam menghasilkan pangan yang aman. Kunci utama HACCP adalah antisipasi bahaya dan identifikasi titik pengawasan yang mengutamakan tindakan pencegahan daripada mengandalkan kepada pengujian produk akhir. Di Australia, sistem HACCP telah dipadukan dengan ISO 9000:2000 yang diterbitkan International Organization of Standardization (ISO), dan disebut sebagai Safe Quality Food (SQF) 2000 (Thaheer, 2005). Saat ini sistem HACCP pun telah diintegrasikan ke dalam sistem mutu lain seperti ISO 15161:2001 dan ISO 22000:2005. Badan Standarisasi Nasional telah mengadopsi sistem HACCP dari Codex dan menerbitkannya melalui dokumen SNI 01-4852-1998.

Pelaksanaan sistem HACCP tak pernah lepas dari pelaksanaan persyaratanpersyaratan dasar (prerequisite program). Sistem jaminan mutu keamanan pangan 
harus diawali dengan pelaksanaan Good Manufacturing Practices (GMP) dan Sanitation Standard Operational Procedure (SSOP). Di Indonesia, GMP dikenal dengan nama Cara Produksi Makanan yang Baik (CPMB) yang telah diatur melalui Keputusan Menteri Kesehatan RI No. 23/Menkes/SK/I/1978 dan Cara Produksi Pangan yang Baik untuk Industri Rumah Tangga (CPPB-IRT) yang diatur melalui Keputusan Kepala Badan Pengawas Obat dan Makanan No. HK.00.05.5.1639 tanggal 30 April 2003.

\section{RUMUSAN MASALAH}

Masalah dalam penelitian ini dirumuskan sebagai berikut :

"Bagaimana menerapkan Hazard Analysis Critical Control Point (HACCP) Sebagai Model Kendali Mutu dan Penjaminan Mutu Produksi Pangan Pada Pengolahan Pastry?

\section{TUJUAN PENULISAN}

a. Menganalisis tahapan-tahapan penting dalam pengolahan pastry untuk menjamin mutu pastry.

b. Mengevaluasi cara pengawasan dan pengendalian mutu pada pengolahan pastry

c. Mengetahui kelayakan dasar dan tingkatan penerapan HACCP dari Unit Pengolahan pastry

\section{KAJIAN PUSTAKA}

\section{Hazard Analysis Critical Control Point} (HACCP)

Standar ini merupakan salah satu sistem standar mutu yang menggunakan model jaminan mutu dengan berdasarkan keamanan pangan (food safety) sebagai pendekatan utama. Dikembangkan pertama kali oleh NASA, U.S. Army Natick Research dan Developtment laboratories Nat. Aeronautics and Space Administration pada tahun 1960. Pemaparan pertama pada masyarakat mengenai system HACCP ini dilakukan pada tahun 1971 si U.S. Penyusunan standar ini mengacu pada ketentuan-ketentuan :
1. CAC/RCP1-1969, REV.4-2003

2. SNI 01-4852-1998

3. Pedoman BSN 1004

HACCP adalah suatu piranti atau instrumen untuk menilai bahaya dan menetapkan system pengendalian yang memfokuskan pada pencegahan daripada mengandalkan sebagian besar pengujian produk akhir. Setiap system HACCP mampu mengakomodasi perubahan seperti rancangan peralatan maju, prosedur pengolahan atau perkembangan teknologi.

Karakteristik HACCP meliputi:

- Pendekatan sistematik

- Proaktif

- Usaha dari suatu tim (tim effort)

- Teknik common sense

- Sistem hidup dan dinamik

Alasan dikembangkannya HACCP adalah :

1. Terdapat produk-produk tercemar berupa

- Berbagai jenis bahan yang berbahaya

- Terjadi diseluruh dunia

- Terdapat tiga jenis bahaya : biologis, kimia dan fisika

- Berimplikasi terhadap kesehatan manusia

- Berimplikasi biaya yang sangat besar

2. Inspeksi di akhir jaluran (End of line inspection) yang tidak dapat memberikan tingkat jaminan sampai tingkat keyakinan yang diperlukan

\section{Prinsip-prinsip HCCP :}

Prinsip 1

Berkaitan dengan analisa bahaya

Prinsip 2

Menentukan titik kendali krisis

Prinsip 3

Menetapkan batas kritis

Prinsip 4

Menetapkan system pemantauan pengendalian TKK/ prosedur monitoring

Prinsip 5

Menetapkan tindakan perbaikan yang dilakukan jika hasil pemantauan menunjukkan bahwa suatu titik kendali krisis tertentu tidak terkendali/ menetapkan tindakan koreksi

Prinsip 6 
Menetapkan prosedut verifikasi untuk memastikan bahwa system HACCP bekerja secara efektif

Prinsip 7

Menetapkan dokumentasi mengenai semua prosedur dan catatan yang sesuai dengan prinsip-prinsip dan penerapannya.

Penerapan prinsip-prinsip HACCP terdiri dari tugas-tugas berikut:

\section{Pembentukan Tim HACCP}

Produsen pangan harus menjamin bahwa pengetahuan dan keahlian spesifik produk tertentu tersedia untuk pengembangan program HACCP yang efektif. Secara optimal, hal tersebut disertai dengan pembentukan sebuah tim dari berbagai disiplin ilmu. Apabila beberapa keahlian tidak tersedia, diperlukan konsultan dari pihak luar. Lingkup dari program HACCP harus diidentifikasikan. Lingkup tersebut harus menggambarkan segmen-segmen mana saja dari rantai pangan tersebut yang terlibat dan penjejangan secara umum bahayabahaya yang dimaksud (yaitu meliputi jenjang bahaya atau hanya jenjang tgertentu). Syarat-syarat tim : Tim multi disipliner (lebih dari 1 orang), Terlatih HACCP, Dari bagian atau departemen yang berlainan, Bisa menggunakan bantuan tenaga ahli (trade and industry association, independence, expert).

\section{Deskripsi Produk}

Gambaran lengkap dari produk, termasuk informasi mengenai komposisi, struktur fisika/kimia (termasuk Aw, pH, dll), perlakuan-perlakuan mikrosidal (seperti perlakukan pemanasan, pembekuan, penggaraman, pengasapan, dll), pengemasan, kondisi penyimpanan dan daya tahan serta metode pendistribusian.

\section{Identifikasi Rencana Penggunaan}

Rencana penggunaan harus didasarkan pada kegunaan-kegunaan yang diharapkan dari produk oleh pengguna produk atau konsumen. Hal-hal spesifik, kelompokkelompok populasi yang riskan, seperti pembuatan pakan mungkin perlu dipertimbangkan.
Identifikasi pengguna produk yang ditujukan. Konsumen sasarannya dengan referensi populasi yang peka (sensitive).

Disesuaikan, apakah produk ditujukan untuk konsumsi umum atau apakah dipasarkan untuk kelompok populasi yang peka.

Lima kelompok populasi yang peka :

- Manula

- Bayi

- Wanita hamil

- Orang sakit

- Orang dengan daya tahan terbatas (immunocompromised)

\section{Penyusunan Bagan Alir}

Bagan alir harus disusun oleh tin HACCP. Dalam diagram alir harus membuat semua tahapan dalam operasional produksi. Pada saat penerapan HACCP, perhatian harus diberikan pada saat tahapan operasi secara spesifik.

Syarat-syarat pembuatan bagan alir :

- Disiapkan oleh Tim HACCP

- Dibuat untuk setiap spesifik produk

- Meliputi semua langkah proses

- Satu diagram alir dapat digunakan untuk beberapa item dengan kategori proses sejenis

- Memungkinkan analisa bahaya pada setiap langkah

- Dapat menggunakan symbol dan nomor

\section{Kepastian di lapangan terhadap bagan} alir

Tim HACCP sebagai penyusun bagan alir harus mengkonfirmasikan operasional produksi dengan semua tahapan dan jam operasi serta mengadakan perubahan bagan alir bilamana perlu.

Diagram alir proses yang harus di validasi :

- Mengamati aliran proses

- Kegiatan pengambilan sample

- Wawancara

- Operasi rutin/non-rutin Hal-hal yang harus di verifikasi :

- Diperiksa di tempat produksi dan ditelusuri secara berurutan

- Akurasi

- Kelengkapan 
- Pengelompokan kategori

6. Daftar semua bahaya potensial yang berkaitan dengan tahapan, pengadaan suatu analisa bahaya dan menyarankan berbagai pengukuran untuk mengendalikan bahaya-bahaya yang teridentifikasi (lihat prinsip1)

Tim HACCP harus membuat daftar bahaya yang mungkin terdapat pada tiap tahapan dari produksi utama, pengolahan, manufaktur dan distribusi hingga sampai pada konsumen.

Tim HACCP harus mengadakan analisa bahaya untuk mengidentifikasi program HACCP dimana bahaya yang terdapat secara alami bahwa batas-batas dan cara menguranginya hingga batas-batas yang dapat diterima adalah penting terhadap produksi yang aman.
Dalam mengadakan analisa bahaya, kemungkinan adanya bahaya terdapat sebagai berikut :

- Terdapatnya bahaya dan pengaruh yang berat dari kesehatan yang merugikan;

- Evaluasi secara kualitatif dan/atau kuantitatif dari kehadiran bahaya;

- Perkembang biakan dan daya tgahan hidup mikroorganisme-mikroorganisme tertentu

- Produksi terus-menerus toksin-toksin pangan , unsur-unsur fisika dan kimia; dan

- Kondisi-kondisi yang memacu keadaan diatas

Tim harus mempertimbangkan apakah tindakan pengendalian, jika ada yang dapat diterapkan untuk setiap bahaya. Lebih jauh tindakan pengendalian disyaratkan untuk mengendalikan bahaya-bahaya yang spesifik dan lebih jauh, satu bahaya dikendalikan oleh tindakan yang spesifik.

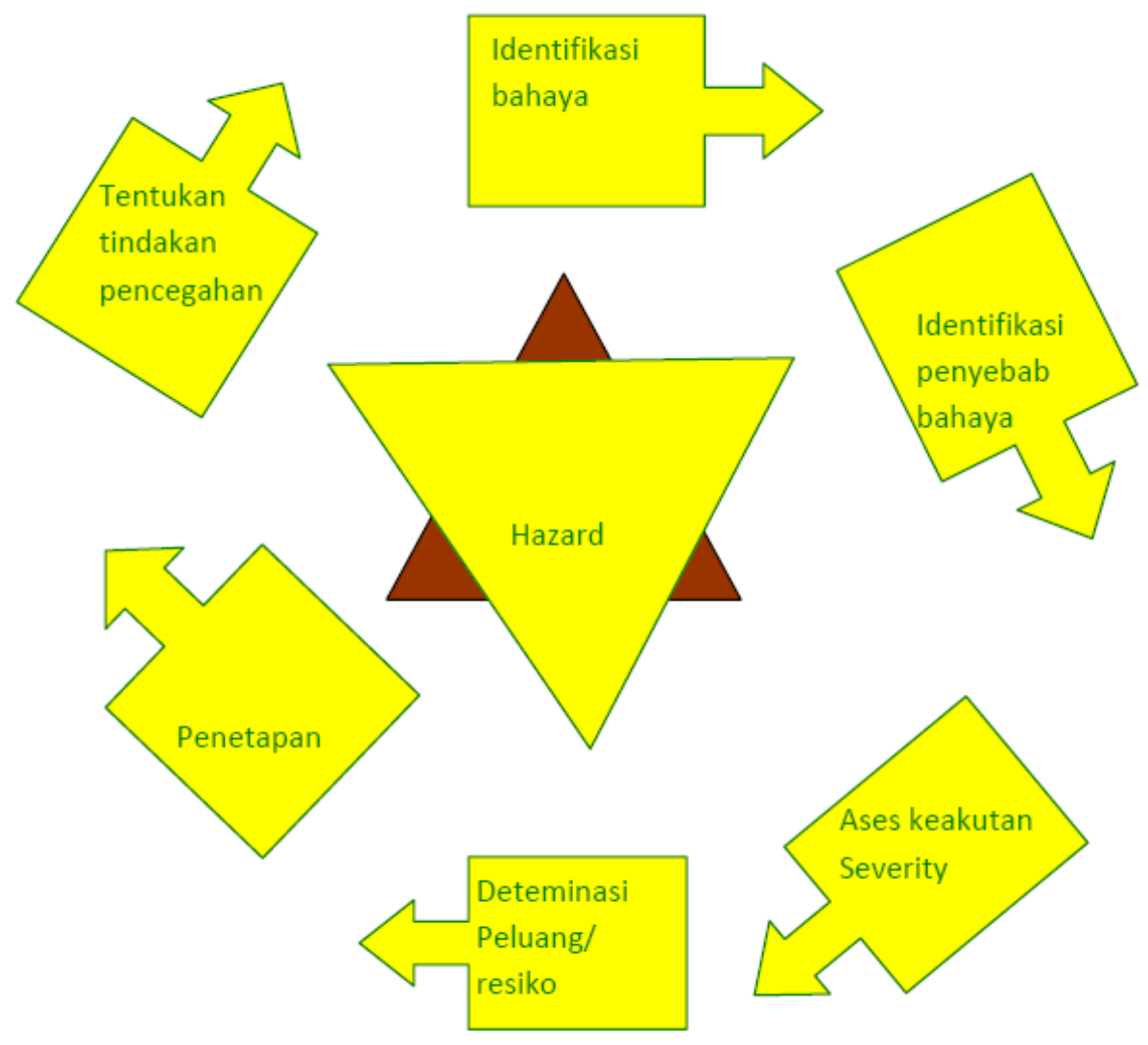


Identifikasi Bahaya :

- Spesifikasi Standar (SNI, CAC. ISO, dll)

- Persyaratan Regulasi (Depkes, Deptan, FDA, POM)

- Persyaratan Pelnanggan

- Pengalaman Perusahaan

- Literatur

\section{Identifikasi penyebab bahaya :}

- Kontaminasi : Pekerja, bahan lain, lingkungan, metide penanganan

- Tumbuh dan berkembang dari produk

Tingkat keseriusan bahaya/ severity :

- Keseriusan bahaya dapat ditetapkan dengan melihat dampaknya terhadap kesehatan konsumen, dan juga dampak terhadap reputasi bisnis

- Keseriusan bahaya juga dapat dinilai rendah, sedang, tinggi

\section{Pengujian Risiko :}

- Definisi : Peluang kemungkinan suatu bahaya akan terjadi

- Dalam keamanan pangan makanan ditetapkan berdasarkan kategori risiko

- Pendekatan yang sederhana adalah dengan mengelompokkan produk menjadi suatu kategori resiko: Tinggi, sedang, rendah

- Suatu alternative adalah dengan membuat matriks risiko berdasarkan siatu kisaran faktor

- Suatu pendekatan yang sederhana pada kategori risiko makanan disajikan berikut ini

\section{Tindakan pencegahan :}

- Kegiatan untuk mencegah, menghilangkan atau mengurangi bahaya sampai ketingkat yang dapat diterima

- Tindakan pencegahan berkaitan sengan sumber bahaya dan tingkat teknologi yang cukup untuk mencapai tujuan tersebut

\section{Penentuan TKK/ Titik Kendali Kritis (CCP) (lihat prinsip 2)}

Ada lebih dari satu TKK di mana pengendalian dilaksanakan menuju bahaya yang sama. Penentuan dari satu TKK pada sistim HACCP dapat dipermudah dengan penerapan pohon seperti pada Diagram 2, dimana menunjukkan pendekatan pemikiran yang logis :

\section{CRITICAL CONTROL POINT}
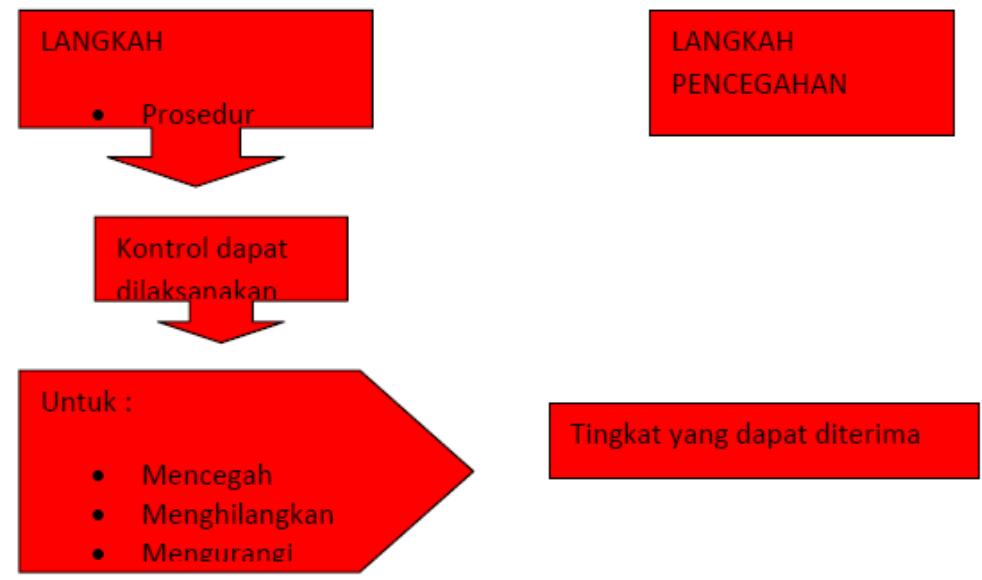
8. Penentuan batas-batas kritis (critical limits) pada tiap TKK (lihat prinsip3)

Batas-batas limit harus ditetapkan secara spesifik dan divalidasi apabila memungkinkan untuk setiap TKK. Dalam beberapa kasus lebih dari satu batas kritis akan diuraikan pada suatu tahap khusus. Seringkali criteria digunakan termasuk ukuran-ukuran suhu, waktu, tingkat kelembapan, $\mathrm{pH}$, AW keberadaan chlorine, dan parameter-parameter sensori seperti penampakan visual dan tekstur. Batas kritis harus ditentukan untuk setiap TKK. Dalam beberapa kasus batas kritis criteria pengukurannya antara lain suhu, waktu, tingkat kelembapan, $\mathrm{pH}$, $\mathrm{Aw}$ dan ketersediaan chlorine dan parameter yang berhubungan dengan pancaindra (penampakan dan tekstur).

Penetapan batas kritis meliputi :

- Satu atau lebih toleransi yanh harus dipenuhi untuk menjamin bahwa suatu CCP secara efektif mengendalikan bahaya mikrobiologis, kimia, fisika

- Semua factor yang tekait dengan keamanan harus diidentifikasi

- Tingkat dimana setiap factor menjadi batas aman dan tidak aman (.....> batas kritis)

- Memisahkan kondisi yang dapat diterima atau tidak

- Harus spesifik dan jelas: Batas maksimum, minimum atau keduanya;

- Harus berkaitan denagn tindakan pengendalian dan mudah dipantau

Apabila HACCP disusun tenaga ahli :

- Perusahaan harusmemastikan bahwa Control Limits dapat diaplikasikan pada operasi, produk, atau kelompok produk secara spesifik

- Terukur Tipe-tipe Control Limits:

- Chemical Limit

- Physical Limits

- Microbiological Limits

\section{Penyusunan sistem monitoring untuk setiap TKK (lihat prinsip 4) \\ Monitoring merupakan kegiatan yang dijadwalkan atau pengamatan terhadap TKK}

yang berhubungan batas kritis. Prosedur monitoring harus menemukan ketidak terkendalian dalam TKK, menetapkan informasi waktu secara ideal untuk tindakan perbaikan yang dilaksanakan untuk mengembalikan pengendalian proses sebelum dilakukan penolakan produk.

Data yang diperoleh dari kegiatan monitoring harus di evaluasi oleh petugas yang ditunjuk sesuai dengan pengetahuann dan kewenangannya untuk melaksanakan tindakan perbaikan bila terjadi indikasi. Apabila pelaksanaa monitoring tidak berkesinambungan, maka jumlah atau frekuensi monitoring harus cukup untuk menjamin TKK berada dalam pengendalian.

Sebagian besar prosedur monitoring dilakukan secara cepat, karena berhubungan dengan proses yang berjalan dan dapat dilakukan analisa pengujian dalam waktu singkat. Tindakan fisika dan kimia lebih disukai karena lebih cepat dari p;ada tgindakan mikrobiologi. Semua catatan dan dokumen yang terkait dengan kegiatan monitoring TKK harus ditanda-tangani oleh ortang yang melakukan monitoring dan oleh petugas perusahaan yang bertanggung-jawab sebagai peninjau.

Cara menentukan frekuensi monitoring tgerus menerus :

- Seberapa jauh variasi data selama proses, semakin besar variasi frekuensi semakin dekat

- Seberapa dekat antara nilai normal dengan CL, semakin dekat nilai normal dengan CL semakin sering dilakukan monitoring

\section{Penetapan tindakan koreksi (lihat prinsip 5)}

Tindakan perbaikan yang spesifik untuk setiap TKK harus dikembangkan dalam system HACCP agar dapat menangani p;enyimpangan bila terjadi.

Tindakan-tindakan harus menjamin bahwa TKK telah berada dibawah kendali. Tindakan-tindakan iktu tgermasuk disposisi yang tepat dari produk yang terpengaruh. Penyimpangan dan prosedur disposisi harus didokumentasikan dalam catatan HACCP. 
Tujuan tindakan koreksi :

- Menjamin eliminasi potensi bahaya

- Mempunyai rencana pasti tindakan pada setia CCP

- Tindakan koreksi diperlukan untuk mengendalikan proses

Dua level tindakan koreksi / CA:

- CA untuk hasil monitoring mempunyai trend keluar dari CL

- CA untuk hasil monitoring melampaui krisis

Disposisi produk tidak sesuai :

1. Tahan produk

2. Determinasi apakah produk membawa efek bahaya keamanan produk

- Berdasarkan evaluasi tenaga ahli

- Berdasarkan pengujian fisika, kimia, mikrobiologi

3. Disposisikan produk
- Reproses menjadi produk baru

- Diproses menjadi produk lain yang kurang sensitive

- Musnahkan produk tidak sesuai

- Dilepas

11. Penetapan prosedur verifikasi (lihat prinsip 6)

Menetapkan prosedur verifikasi. Metode audit dan verifikasi, prosedur dan pengujian, mencakup pengambilan contoh secara acak dan menganalisa, dapat dipergunakan untuk menentukan apakah system HACCP bekerja secara benar. Frekuensi verifikasi harus cukup untuk mengkonfirmasikan bahwa system HACCP bekerja secara efektif.

12. Penetapan dokumen dan pencatatan (lihat prinsip 7)

\section{Urutan Logis Penerapan HCPP}

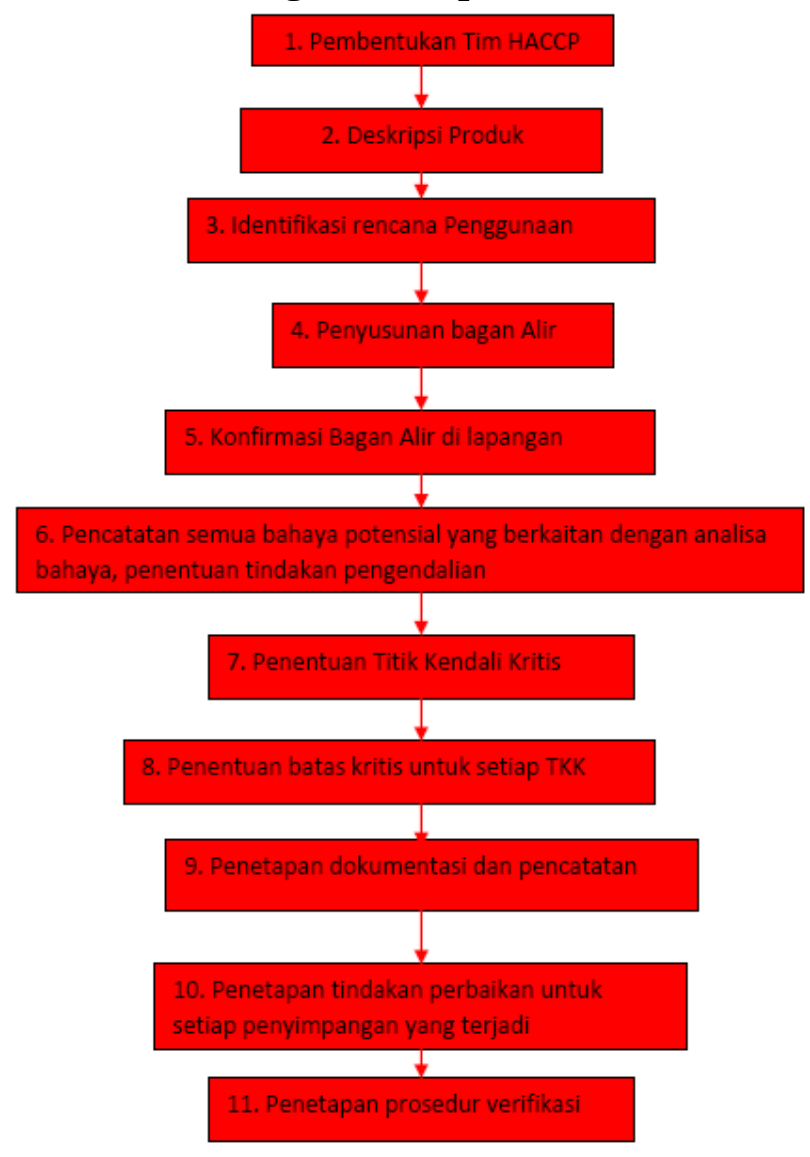

Pohon keputusan Penentuan TKK 


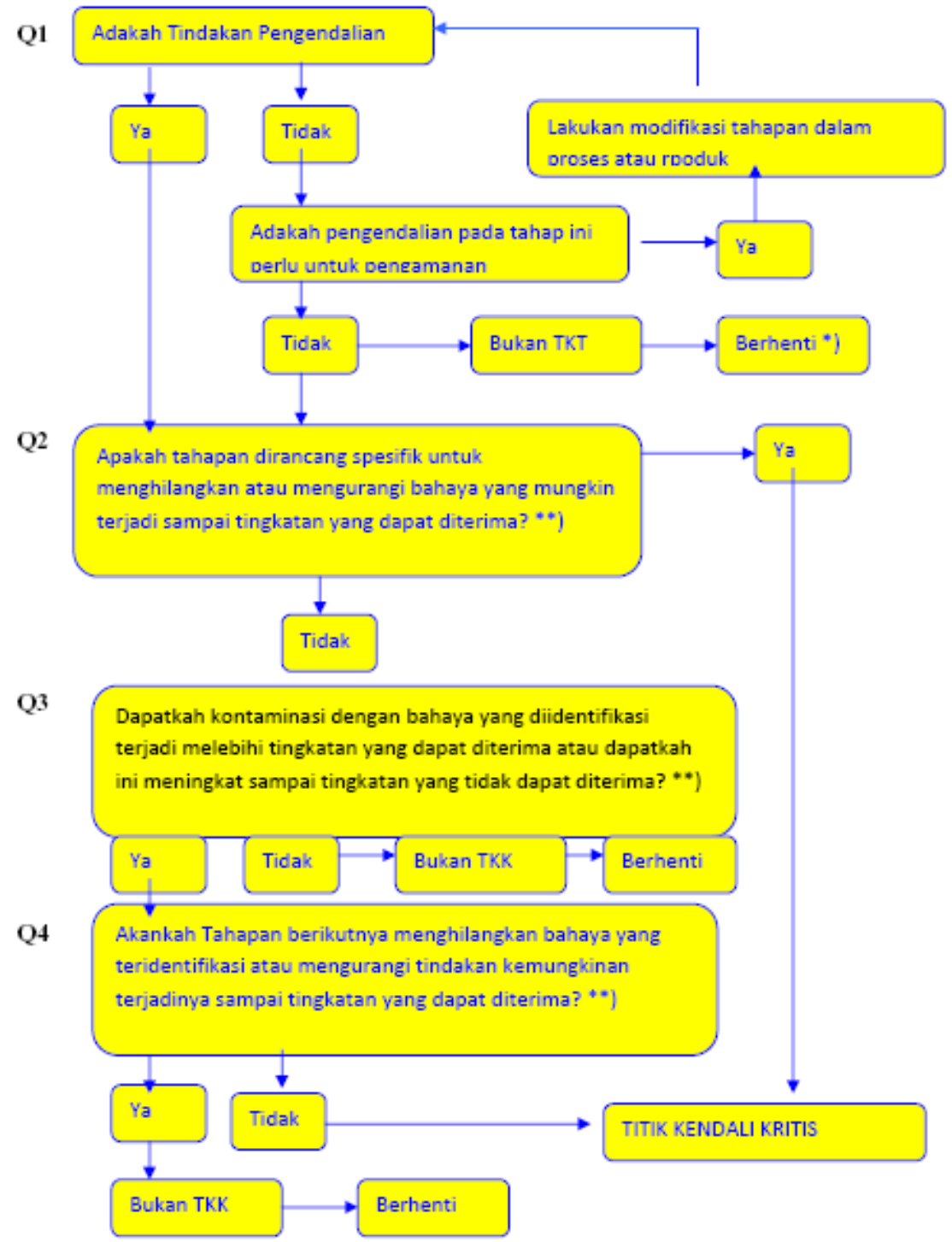

\section{METODOLOGI PENELITIAN}

Penelitian ini bersifat deskriptif yaitu memberikan gambaran yang jelas tentang kondisi nyata subyek penelitian. Metode yang digunakan adalah studi kasus (case study) yakni bentuk penelitian yang mendalam tentang suatu lingkungan termasuk manusia di dalamnya. Bahan untuk case study dapat diperoleh dari sumbersumber seperti laporan hasil pengamatan, literatur atau pustaka, laporan/keterangan dari orang atau lembaga yang banyak tahu tentang hal yang diselidiki (Nasution, 2000). Pengamatan dilakukan pada upaya - upaya pencegahan ( preventive measure ) terhadap produk yang diterima di unit pengolahan pastry baik yang dibeli langsung ataupun diterima atau dikirim oleh suplier ke unit pengolahan. Untuk mendapatkan data mengenai mutu produk dilakukan pada saat bahan baku diterima di unit pengolahan dan pada saat sebelum melalui salah satu tahapan proses produksi dan sesudah melalui salah satu tahapan produksi yang dianggap merupakan Critical Control Point (CCP). Analisa dilakukan secara kualitatif dan kuantitatif berupa pengolahan data uji organoleptik dan mikrobiologi.

\section{HASIL PENELITIAN DAN PEMBAHASAN}


Untuk menentukan titik-titik kritis dalam pengolahan pastry dilakukan dengan menggunakan metode Decision Tree yang merupakan suatu set alat pengambilan keputusan yang terdiri dari pertanyaanpertanyaan untuk menentukan titik-titik kritis dalam suatu proses pengolahan bahan pangan. Dari pengamatan dan observasi yang dilakukan serta hasil pengolahan data menggunakan Decision Tree diketahui bahwa titik-titik kritis (CCP) dari pengolahan pastry tersebut adalah sebagai berikut : Langkah pengujian ini dilakukan dengan maksud untuk memastikan apakah tahapantahapan quality control yang dianggap CCP oleh unit pengolahan pastry memang benar sebagai titik kritis (CCP). Pengujian ini dilakukan dengan membanding kondisi pastry pada saat tahapan awal dengan kondisi pastry pada tahapan-tahapan yang dianggap CCP dengan menggunakan metode uji t-test (uji perbedaan) dan uji Spearman-rho (uji korelasi).

Hasil uji t-test untuk pengujian titik kritis (CCP) berdasarkan nilai uji ALT pada tahapan awal dengan tahapan yang dianggap CCP adalah sebagai berikut : Dari hasil uji ttest diketahui bahwa nilai ALT pada kondisi awal dan pada tiap CCP terjadi perbedaan (sig. < 0,05). Hal ini membuktikan terjadi kondisi mikrobiologi produk pada saat awal dan pada tiap-tiap tindakan CCP, dan dampak tindakan pengendalian terhadap produk pada tiap-tiap CCP adalah sebagai berikut: tahapan 1 melakukan tindakan penanganan pada tiap CCP dan bentuk tindakan tersebut dapat menurunkan nilai ALT pada produk pastry (koef. Korelasi negatif; sig. < 0,05). Tahapan 2 melakukan tindakan penanganan pada tiap CCP dan bentuk tindakan tersebut dapat menurunkan nilai ALT pada produk pastry (koef. Korelasi negatif; sig. < 0,05). Begitu juga yang terjadi pada tahapan 3 tindakan penanganan yang dilakukan pada tiap CCP dan bentuk tindakan tersebut dapat menurunkan nilai ALT pada produk Pastry (koef. Korelasi negatif; sig. $<0,05$.

Pada dasarnya HACCP tidak merupakan suatu program yang berdiri sendiri tetapi merupakan bagian dari suatu sistem yang lebih besar dalam sistem pengawasan. Agar fungsi penerapan PMMT/HACCP dapat berjalan lebih efektif. Setiap unit pengolahan yang akan menerapkan PMMT/HACCP harus memenuhi persyaratan kelayakan dasar (prerequisite program) yang terdiri dari 2 bagian pokok. Hasil penilaian yang telah dilakukan saat penelitian pada ketiga tahapan adalah sebagai berikut : Hasil dari audit pada tahapan 1 adalah langkah pencatatan tidak akurat, tindakan pencegahan yang dituangkan dalam buku panduan tidak diikuti dengan baik dan prosedur pemantauan tidak diikuti dengan baik., hasil audit pada tahapan 2 adalah langkah untuk koreksi terhadap penyimpangan atau kesalahan yang terjadi dilakukan koreksi tetapi tidak di file dengan baik, hasil audit pada tahapan 3 adalah langkah pencatatan penerapan HACCP telah dilakukan dengan baik dan tindakan pencegahan, prosedur pemantauan serta tindakan koreksi dilakukan dengan baik. Audit merupakan salah satu rangkaian kegiatan dalam pengawasan PMMT. Output dari pelaksanaan audit berupa level atau tingkat efektifitas penerapan HACCP yang digunakan. Sedangkan output dari verifikasi audit adalah selain kedua hal tersebut, juga untuk menentukan apakah suatu unit pengolahan memenuhi syarat untuk diberikan perpanjangan rekomendasi penerapan HACCP.

\section{KESIMPULAN}

Kesimpulan yang dapat diambil dari hasil penelitian ini antara lain adalah :

1. Hasil identifikasi titik kritis (CCP) berdasarkan uji t-test dan Uji Korelasi pada ketiga tahapan diketahui bahwa untuk tahapan 1 pada tahapan Raw Material, Final Checking, Final Weighing, Packing \& Labeling, dinyatakan sebagai titik kritis (CCP). Pada tahapan 2 titik kritis (CCP) pada tahapan Raw Material, Grading, Weighing, Packing \& Labeling. Pada tahapan 3 titik kritis (CCP) pada tahapan 
Raw Material, Pree Checking, Final Weighing, Packing \& Labeling.

2. Ketiga tahapan pengolahan pastry telah menerapkan pengendalian mutu penanganan sesuai dengan konsep HACCP dengan menerapkan 7 prinsip HACCP dan melakukan pengawasan serta melakukan upaya-upaya pencegahan atau preventive measure pada Standar Prosedur Operasi Sanitasi (SPOS) dan Standar Operasi Pengolahan (SOP).

3. Dalam pemantauan/monitoring CCP ketigatahapan telah menerapkan prosedur pemantauan, pengendalian titik kritis terdiri dari komponen : what, how, frequency, who. Tiap tahapan memiliki sistem pemantauan/monitoring dengan ciri-ciri khusus penanganan tersendiri.

\section{DAFTAR PUSTAKA}

Badan Standarisasi Nasional ,1991. Standar Nasional Indonesia, 01- 2346-1991. Petunjuk Pengujian Organoleptik Produk Pastry. Jakarta. ,1991. Standar Nasional Indonesia, 014852-1998. Sistem Analisa Bahaya dan Pengendalian Titik Kritis (Hasard Analysis Critical Cintrol Point-HACCP) serta Pedoman Penerapannya.. Jakarta. ,1991. Standar Nasional Indonesia, 012705-1992. Pastry. Jakarta

Codex Alimentarius, 1997. HACCP System and guidelines for its Application, Annex to CACRCP I 1969 page 3 in Codex Alimentarius. Food Hygiene Basic Texts. Food and Agricultural Organization of The United Nation
Direktorat Jenderal Pengawasan Obat dan Makanan, 1990. Peraturan Menteri Kesehatan Republik Indonesia Nomor : 722 / MENKES / PER / IX / 88. Tentang Bahan Tambahan Makanan. Departemen Kesehatan Republik Indonesia. Jakarta.

Forsythe, Sj and P.R. Hayes, 1998. Food Hygiene, Microbiology and HACCP. Third Edition Aspen Publishers, Inc. Gaithersburg, Maryland.J

Khomsan, A. 2004. Pangan dan Gizi untuk Kesehatan. PT Rajasa Grafindo Persada. Jakarta.

Krisnamurti, B.2003. Food Security Module Indonesia. Paper prsented at the Roles of Agriculture International Conference 20-22 October 2003

Marzuki, 2002. Metodologi Riset. Bagian Penerbitan Fakultas Ekonomi Universitas Islam Indonesia. Yogyakarta.

Maxwell, $\quad$ D:C.Levin;M.A.Klemeseu; M.Rull;S.Morris and C.Aliadeke.2000. Urban Livelihoods and Food Nutrition Security in Greater Accra, Ghana.Ifpri in Collaborative with Noguchi Memorial fr Medial Research and World Health Organization. Research Report No.112 Washington D.C.

Sudjana, 1998. Metode Statistika. Penerbit Tarsito Bandung.

Winarno, F.G,1998. Kimia Pangan dan Gizi. Cetakan 5. P.T. Gramedia. Jakarta. 